\title{
Inovasi Gerakan Gelar Gulung sebagai Solusi Pemenuhan Pangan Mandiri di Kota Yogyakarta
}

\author{
Farida Rahmawati ${ }^{1}$, Ana Chusniatul Hidayah ${ }^{2}$, Aida Nur Faizah ${ }^{3}$, Ahmad Falahuddin ${ }^{4}$, \\ M. Adryan Okuputra ${ }^{5}$
}

\begin{abstract}
Abstrak
Gerakan Gelar Gulung merupakan aksi tanggap warga dalam hal pemenuhan kebutuhan pangan masyarakat yang terdampak oleh Pandemi COVID-19 di Desa Tegalweru Kecamatan Tegalrejo Kota Yogyakarta. Tujuan penelitian ini adalah mengeksplorasi aksi dan inovasi yang dilakukan Gerakan Gelar Gulung dalam memenuhi kebutuhan pangan secara mandiri sebagai upaya mitigasi dampak pandemi COVID-19. Analisis dalam penelitian ini dilakukan dengan metode deskriptif melalui pengumpulan data-data kualitatif yang diperoleh melalui metode observasi, wawancara, dan kepustakaan. Hasil penelitian menunjukkan bahwa terdapat 5 aksi dalam Gerakan Gelar Gulung yaitu a) aksi mapping warga mandiri pastisipatif, b) aksi tanggap darurat pangan, c) aksi sosial kemandirian ekonomi, d) aksi jejaring pangupa jiwa, dan e) aksi berkebun lumbung pangan. Implementasi Gerakan Gelar Gulung ini mendapatkan respon positif dari berbagai pihak dikarenakan program yang sedang berjalan ini mampu meningkatkan ketahanan pangan dalam masa pandemi COVID-19 dan mendorong kemandirian ekonomi dalam jangka panjang.
\end{abstract}

Kata kunci: Gerakan Gelar Gulung, Pandemi COVID-19, Ketahanan Pangan

\begin{abstract}
Gelar Gulung is a citizen action in terms of fulfilling the food needs of society who affected by COVID-19pandemic. The purpose of the study is exploring what actions and innovations which were carried out by Gelar Gulung action in fulfilling food needs to mitigate the impact of COVID-19 pandemic, especially in Tegalweru Village. The analysis in this study was done using descriptive methods by collecting qualitative data obtained through observation, interview, and literature study. The results showed that there were 5 actions, namely a) participatory mapping, b) food emergency response actions, c) sufficiency economy, d) community leaders' network actions, and e) urban farming. The implementation of Gelar Gulung action received positive response from the stakeholders as this ongoing program was able to increase food security during the COVID-19pandemic and encourage long-term economic sufficiency.
\end{abstract}

Keywords: Gelar Gulung Action, COVID-19 Pandemic, Food Security

\section{Pendahuluan}

Tahun 2019 hingga saat ini menjadi tahun yang akan selalu diingat oleh dunia. Pasalnya pada tahun 2019 menjadi tahun awal bagi munculnya virus baru yang menggemparkan dunia karena gejala dan dampak yang ditimbulkan. Virus tersebut bernama SARS-CoV-2 atau lebih dikenal dengan COVID-19 (Coronavirus Disease-19). COVID-19 merupakan virus baru yang belum pernah dialami manusia sebelumnya. COVID-19 diduga muncul pertama kali pada bulan Agustus 2019 silam di Wuhan, China dan telah menjadi wabah serta menyebar sangat cepat ke berbagai negara tetangga dan merambah ke seluruh belahan dunia hanya dalam hitungan bulan, sehingga WHO (World Health Organization) menyatakan dengan resmi pada Maret 2020 bahwa virus COVID-19 sebagai pandemi. Berawal dari bulan Maret 2020, pandemi COVID-19 kemudian berkembang menjadi isu global yang kemudian hampir semua belahan dunia terdampak.

Indonesia juga tidak luput dari dampak pandemi COVID-19. Berdasarkan Komite Penanganan COVID-19 dan Pemulihan Ekonomi Nasional bahwa pada 16 Juli 2021 terdapat

\footnotetext{
${ }^{1}$ Fakultas Ekonomi, Universitas Negeri Malang (email korespondensi: farida.rahmawati.fe@um.ac.id)

${ }^{2}$ Fakultas Ekonomi, Universitas Negeri Malang (email: ana.chusniatul.1804326@students.um.ac.id)

${ }^{3}$ Fakultas Ekonomi, Universitas Negeri Malang (email: aida.nur.1804326@students.um.ac.id)

${ }^{4}$ Fakultas Ekonomi, Universitas Negeri Malang (email: ahmad.falahudin.1804326@students.um.ac.id)

${ }^{5}$ Fakultas Ekonomi, Universitas Negeri Malang (email: m.adryan.1804326@students.um.ac.id)
} 
Farida Rahmawati, Ana Chusniatul Hidayah, Aida Nur Faizah, Ahmad Falahuddin, M. Adryan Okuputra Inovasi Gerakan Gelar Gulung sebagai Solusi Pemenuhan Pangan Mandiri di Kota Yogyakarta

2.780.803 pasien yang teridentifikasi positif COVID-19 dengan lonjakan kasus yang terus bertambah setiap harinya (Satuan Tugas Penanganan COVID-19 Indonesia, 2021). Dampak yang ditimbulkan dan dirasakan oleh seluruh penduduk Indonesia dari virus ini sangat beragam, selain pada sektor kesehatan, virus ini mempengaruhi sektor lainnya seperti sektor pendidikan, pekerjaan atau tenaga kerja, politik, bahkan sektor ekonomi.

Angka yang terus naik membuat Pemerintah Indonesia mau tidak mau harus bergegas mengambil kebijakan untuk mengatasinya dengan Pemberlakuan Pembatasan Kegiatan Masyarakat (PPKM) yang berlaku di Pulau JawaBali dalam Instruksi Mendagri No. 14 Tahun 2021. Kebijakan PPKM diambil mengingat kasus penularan COVID-19 di Indonesia tidak mengalami penurunan. PPKM Mikro diterapkan dengan tujuan untuk membatasi aktivitas yang mengarah pada kerumunan dan menegaskan kepatuhan masyarakat terhadap protokol kesehatan. Protokol kesehatan yang diterapkan yakni 3M (Memakai Masker, Mencuci tangan dan Menjaga Jarak) ditujukan untuk menekan pertumbuhan kasus virus corona di Indonesia. Namun kebijakan yang dianggap tepat untuk mengatasi penyebaran virus di sektor kesehatan justru membuat sektor lainnya memburuk terutama terhadap sektor ekonomi. Banyak aktivitas ekonomi yang berjalan menjadi terhambat bahkan terhenti untuk sementara waktu. Lebih khusus lagi, sektor ekonomi mengalami dampak-dampak seperti tenaga kerja terpaksa berhenti, UMKM mikro terpaksa tutup bahkan gulung tikar, dan industri-industri besar mengalami kerugian dan terpaksa melakukan pemutusan hubungan kerja (PHK).

Masalah yang muncul dari kelesuan ekonomi akibat pembatasan sosial mendorong masyarakat untuk bertahan di masa pandemi. Salah satu bentuk upaya mengatasinya ialah kemandirian ekonomi dengan praktik pemenuhan kebutuhan sehari-hari oleh masyarakat itu sendiri. Seperti menanam sayuran, tanaman obat, rempah-rempah, beternak atau budidaya dengan memanfaatkan lahan kosong. Kawasan Rumah Pangan Lestari (KRPL) adalah suatu upaya untuk memenuhi kebutuhan pangan masyarakat dengan memanfaatkan lahan kosong seperti pekarangan rumah untuk budidaya dan bercocok tanam. Prinsip utama KRPL yakni pemanfaatan pekarangan yang ramah lingkungan untuk ketahanan dan kemandirian pangan, diversifikasi pangan berbasis sumber daya lokal, konservasi sumber daya genetik pangan (tanaman, ternak, ikan), menjaga kelestarian genetik pangan melalui kebun bibit, dan peningkatan pendapatan menuju kesejahteraan masyarakat (Pangestu et al., 2020). Hal ini searah dengan tujuan dari Program Gelar Gulung yakni memberikan bantuan dan solusi kepada warga terdampak Pandemi COVID-19 khususnya warga RT 55 RW 02 Kelurahan Karangwaru, Yogyakarta dalam jangka pendek, menengah dan panjang secara berkelanjutan dan membangun ketahanan pangan serta kemandirian ekonomi di lingkungan wilayah rukun tetangga.

Berdasarkan latar belakang yang telah dipaparkan, maka tulisan ini membahas tentang Program Gelar Gulung (GEGU) sebagai bentuk perwujudan dan solusi pemenuhan kebutuhan pangan secara mandiri dan upaya mengatasi pengangguran dengan gerakan sosial dan aksi berbasis paguyuban atau gotong-royong oleh komunitas RT 55 RW 02 Karangwaru Yogyakarta di masa pandemi COVID-19. Penelitian ini bertujuan menarasikan upaya yang telah dilakukan oleh komunitas setempat dalam penerapan dan pemulihan dari dampak pandemi COVID-19, terutama dalam hal solusi memenuhi kebutuhan pangan warga secara mandiri. Melalui pembahasan pada penelitian ini, maka diharapkan dapat menjadi rekomendasi dan solusi bagi daerah lainnya serta saran bagi pengembangan kebijakan darurat sebagai mitigasi dampak pandemi COVID-19.

\section{Kerangka Teori}

Pemberdayaan Ketahanan Pangan Masyarakat

Pemberdayaan merupakan salah satu bentuk pembangunan masyarakat yang bertujuan mengentaskan kemiskinan secara partisipatif. Dalam terminologi yang lebih sederhana, pemberdayaan berarti proses memberikan/mendapatkan keberdayaan. Proses pemberdayaan mengacu pada serangkaian langkah yang dilakukan secara bertahap untuk mengubah masyarakat yang lemah atau belum memperoleh kekuasaan menjadi masyarakat berdaya. Menurut Kartasasmita, pemberdayaan memiliki dua arah, yaitu: (a) berjuang untuk menghilangkan belenggu kemiskinan dan keterbelakangan, dan (b) memperkuat status kelas masyarakat dalam struktur kekuasaan 
(Tampubolon et al., 2006). Pemberdayaan itu sendiri adalah meningkatkan kemampuan masyarakat untuk mendorong kemandirian ekonomi serta menghilangkan kemiskinan dan keterbelakangan. Terciptanya kemandirian ekonomi bukan hanya memberdayakan masyarakat yang belum berdaya, akan tetapi juga memberdayakan masyarakat yang sudah berdaya namun masih kurang dalam kemandiriannya. Pemberdayaan diharapkan tidak membuat ketergantungan masyarakat, pemberdayaan juga harus mengacu kepada kemandirian (Wahyuni, 2018).

Menurut Sumodiningrat (1999: 133134), pemberdayaan masyarakat bisa dikatakan berhasil jika terdapat tiga jalur didalamnya, yaitu: (1) menciptakan iklim dan meningkatkan potensi masyarakat yang berkembang, (2) memperkuat potensi dan daya saing masyarakat, dan (3) memberikan perlindungan. Dengan adanya pemberdayaan akan memberikan masyarakat sumber daya, kesempatan, pengetahuan dan keterampilan untuk meningkatkan kemampuan mereka dalam menentukan masa depan mereka sendiri, berpartisipasi dan mempengaruhi kehidupan masyarakat lainnya (Ife dalam Wahyuni 2018). Untuk mewujudkan usaha tersebut kemudian sangat diperlukan penguatan sumber daya yang ada dalam tujuan meraih kapabilitas masyarakat yang kuat. Sebagai konsep yang erat kaitannya dengan pembangunan sosial, pemberdayaan kemudian harus disertakan dengan penguatan dan pengelolaan modal sosial masyarakat (Ansari et al., 2012). Pada titik inilah kemudian pemahaman dasar dari modal sosial sangatlah dibutuhkan.

Modal sosial merupakan hal yang sangat diperlukan untuk menguatkan nilai-nilai bermasyarakat. Masyarakat yang menyadari keberadaan modal sosial memahami bahwa modal sosial sangatlah penting dalam aktivitas apapun. Modal sosial bukanlah modal dalam arti yang biasa saja seperti harta kekayaan atau uang, akan tetapi modal sosial lebih ke aset atau modal nyata yang penting dalam kehidupan bermasyarakat. Fukuyama mengartikan modal sosial sebagai kumpulan nilai-nilai atau normanorma informal yang terjadi secara spontan diantara para anggota suatu kelompok yang sedang bekerja sama. Norma-norma informal yang spontan berkaitan dengan kebajikankebaijkan tradisional seperti adanya kejujuran, berkomitmen, bertanggung jawab dan norma saling timbal balik (Nasution, 2016).

Adanya modal sosial mampu mendorong partisipasi karena memiliki peran positif dalam dimensi politik. Syahra berpendapat bahwa adanya modal sosial dikarenakan setiap individu tidak mungkin dapat mengatasi masalah secara individu, sehingga diperlukan kebersamaan dan kerjasama baik dengan anggota masyarakat yang berkepentingan untuk mengatasi masalah yang ada (Fathy, 2019). Modal sosial mampu membangun relasi sosial dengan baik, relasi sosial tersebut dapat diberdayakan sebagai modal untuk mendapatkan keuntungan ekonomi dan manfaat sosial. Kepercayaan sebagai salah satu modal sosial sangat berpengaruh terhadap tujuan ataupun masalah yang akan diselesaikan. Field berpendapat bahwa jaringan dengan kepercayaan tinggi bisa berfungsi dengan baik dibandingkan dengan jaringan yang memiliki kepercayaan rendah (Syahli \& Sekarningrum, 2017).

Tujuan dari adanya pemberdayaan adalah kemandirian, salah satunya kemandirian ekonomi. Untuk mendapatkan pemahaman yang comprehensive terhadap kemandirian ekonomi setidaknya ada dua kata yang harus dipahami terlebih dahulu, yaitu kemandirian dan ekonomi. Kemandirian dapat diartikan sebagai suatu kemampuan untuk memikirkan, merasakan, dan melakukan sesuatu sendiri. Menurut Barnadib, kemandirian adalah keadaan seseorang yang dapat menentukan diri sendiri dimana dapat dinyatakan dalam tindakan atau perilaku seseorang dan dapat dinilai meliputi perilaku yang mampu berinisiatif, mampu mengatasi masalah/hambatan, mempunyai rasa percaya diri, dan dapat melakukannya tanpa bantuan orang lain (Misjaya et al., 2019). Istilah kemandirian dapat diartikan dengan hal atau keadaan seseorang yang dapat berdiri sendiri atau tidak bergantung kepada orang lain. Kata yang kedua adalah ekonomi. Sementara itu menurut Kamus Besar Bahasa Indonesia (KBBI) "ekonomi" adalah ilmu mengenai asas-asas produksi, distribusi, dan pemakaian barangbarang serta kekayaan (seperti keuangan, perindustrian, dan perdagangan). Oleh karena itu, kemandirian ekonomi adalah suatu proses atau kegiatan yang memaksimalkan segala kemampuan dan potensi di bidang ekonomi. Kemampuan dan potensi tersebut dilakukan secara mandiri, sehingga kemandirian 
Farida Rahmawati, Ana Chusniatul Hidayah, Aida Nur Faizah, Ahmad Falahuddin, M. Adryan Okuputra Inovasi Gerakan Gelar Gulung sebagai Solusi Pemenuhan Pangan Mandiri di Kota Yogyakarta

ekonomi adalah kemampuan untuk mengatur perekonomian sendiri dan tidak tergantung pada perekonomian orang lain.

Pemberdayaan dalam konteks ketahanan pangan kemudian merujuk pada kemandirian ekonomi dan sosial dalam pengelolaan ketersediaan pangan. Menurut Arifin dimensi ketahanan pangan adalah (a) ketersediaan: produksi, distribusi pangan pokok dan lainnya, berkualitas, aman, bergizi dan berimbang, (b) aksesibilitas: akses pangan, terutama kaum miskin/marginal: subsidi penanggulangan bencana, gender. (c) stabilitas (harga): antar daerah, antar waktu, antar pelaku, konsep cadangan besi, cadangan penyangga, (d) utilisasi: pengolahan, keamanan, pola makan, higienis, sanitasi air, kehalalan, keutuhan, kemanfaatan dan lain sebagainnya (Helmi \& Ali, 2020)to analyze the external and internal factors that affect food security and to formulate strategies for improving food security to facing COVID-19's pandemic in Bukittinggi. The primary data was collected by conducting a focus group discussion, indepht interview and questionnaire filling with purposive sampling technique. The results of descriptive analysis of secondary data indicate that the existing condition of food security in the Bukittinggi shows that the situation of food affordability is the best. The formulation of strategies for improving food security uses the analysis of Internal Factor Evaluation (IFE.

Kemudian dalam pembahasan indikator ketahanan pangan, kerangka penelitian yang digunakan harus mencerminkan realitas yang ada dan sulit untuk diukur secara langsung serta memberikan urutan besaran pada skala tertentu. Menurut Pangaribowo et al. (2013), indikator dalam ketahanan pangan harus dipilih sedemikian rupa untuk memastikan suatu program dapat memenuhi berbagai sifat yang diinginkan. Beberapa sifat didasarkan pada relevansi kebijakan dari indicator (indikator harus kredibel yaitu berakar dalam kerangka konseptual dan teoritis yang solid, cepat tersedia, dan konsisten) serat berdasarkan kriteria ilmiah. Melalui kerangka berpikir diatas dengan menyambungkan dimensi serta indikator keberhasilan ketahanan pangan, makan yang paling relevan dalam kasus Pandemi COVID-19 ini ialah mengacu pada dimensi aksesibilitas dalam hal ini kebertahanan terhadap bencana, karena COVID-19 ini juga termasuk bencana global.
Berdasarkan kerangka berpikir melalui respon komunitas terhadap dampak Pandemi COVID-19 dimana terdapat banyak warga yang kehilangan mata pencaharian. Seperti hasil kajian Bahtiar dan Saragih (2020) yang menyebutkan bahwa mewabahnya COVID-19 semakin melemahkan perekonomian nasional. Berbagai sektor bisnis mengalami perlambatan mulai dari sektor UMKM, pertanian, perkebunan, pariwisata dan lain-lain. Dilatarbelakangi oleh hal itu maka tulisan ini mencoba menggambarkan upaya gotong royong warga RT 55 Kelurahan Karangwaru, Kecamatan Tegalrejo, Kota Yogyakarta dengan gerakan Gelar Gulung yang berupa badan usaha milik RT berbentuk Koperasi, mereka menginisiasi program Gelar Gulung ini sebagai wujud kemandirian ekonomi, warga yang partisipatif, dan bermuara pada ketahanan pangan.

\section{Metode Penelitian}

Penelitian dilakukan di RT 55 Kelurahan karangwaru Kecamatan Tegalrejo Kota Yogyakarta. Lokasi penelitian ditentukan berdasarkan RT inovatif dengan program Gelar Gulung yang bertujuan memberdayakan masyarakat dan meningkatkan ketahanan pangan serta kemandirian ekonomi selama pandemi. Penelitian ini bersifat deskriptif dan dilakukan dengan menggunakan metode desain kualitatif. Menurut Strauss dan Corbin, penelitian kualitatif adalah jenis penelitian yang menghasilkan hasil penelitian, yang hasil penelitiannya tidak dapat dicapai melalui pengukuran statistik atau metode kuantitatif atau pengukuran lainnya (Salim \& Sahrum, 2012). Sementara itu Menurut Mason, penelitian kualitatif bertujuan untuk menghasilkan pemahaman yang komprehensif dan kontekstual berdasarkan sejumlah besar data yang rinci dan bernuansa (Awalurrizqi et al., 2021). Metode ini dipilih karena lebih jelas menggambarkan semua fenomena yang ada di masyarakat.

Penelitian ini menggunakan dua jenis data, yaitu data primer dan data sekunder. Pengumpulan data primer dilakukan melalui observasi, wawancara mendalam dan diskusi. Observasi dilakukan dengan pengamatan langsung atau peninjauan visual secara langsung di lokasi penelitian. Pada saat yang sama, dilakukan wawancara mendalam dan diskusi dengan warga dalam RT 55 (Ketua, pengurus harian, dan warga) Teknik pengumpulan data 
sekunder adalah melalui penelitian kepustakaan. Penelitian kepustakaan adalah suatu metode pengumpulan dan pencarian data melalui dokumen, termasuk dokumen tertulis, foto, gambar, dan file elektronik yang mendukung proses penelitian. Dari seluruh data yang diperoleh telah dilakukan analisis deskriptif untuk mengetahui perkembangan program gelar RT 55 Gurung di Kelurahan Karangwaru, Kecamatan Tegalrejo, Kota Yogyakarta.

\section{Hasil}

Gambaran Umum RT 55 RW 2 Kelurahan Karangwaru

Kelurahan Karangwaru terletak di Kecamatan Tegalrejo, Kota Yogyakarta Provinsi Daerah Istimewa Yogyakarta. Berdasarkan kondisi geografis wilayah Kelurahan Karangwaru merupakan salah satu desa di Kota Yogyakarta yang berada di dekat perbatasan antara Kota Yogyakarta dengan Kabupaten Sleman. Lebih detailnya batas Kelurahan Karangwaru ialah sebelah utara berbatasan dengan Desa Sinduadi, sebelah timur berbatasan dengan Desa Sinduadi, sebelah selatan berbatasan dengan Kelurahan Cokrodiningratan, sebelah barat berbatasan Kelurahan Kricak. Sebagai kawasan padat penduduk yang terletak di Kota Yogyakarta, Karangwaru juga tidak luput dari permasalahan pandemi COVID-19.

Secara demografi, Kelurahan Karangwaru dihuni oleh kelompok masyarakat dengan latar belakang sosial-ekonomi yang beragam. Beberapa warga berprofesi sebagai pengacara dan pengusaha. Selain itu terdapat juga masyarakat yang merupakan kelompok pensiunan TNI dan pegawai PLN. Namun sebagian warga kelurahan lainnya berprofesi sebagai pedagang kecil seperti penjual mie ayam, sempol, gorengan, pembuat karpet dan lain sebagainya. Sehingga kelurahan ini memiliki kontur masyarakat yang berpenghasilan tinggi dan rendah. Ketika pandemi mulai menyerang warga yang berpenghasilan rendah mengalami gangguan ekonomi, dan krisis kebutuhan sehari-hari hingga kehilangan pekerjaan yang berdampak pada terganggunya kehidupan sosial warga. Di balik itu semua, masyarakat diselimuti dengan tingginya rasa sosial dan gotong royong saling bahu membahu mencari solusi bertahan walaupun dengan physical distancinng.

Pembatasan yang diterapkan pemerintah membuat kegiatan ekonomi terhenti untuk sementara waktu dan pemenuhan kebutuhan menjadi sulit. Setidaknya terdapat 21 orang dalam RT 55 Kelurahan Karangwaru yang kehilangan pekerjaannya dan terpaksa menganggur atau sebanyak 800 dari 3000 KK terdampak dalam satu kelurahan. Hal ini kemudian berdampak pada usaha pemenuhan kesejahteraan masyarakat. Kebutuhan akan pemenuhan kualitas hidup yang baik dan sehat - dalam hal ini adalah kebutuhan gizi - menjadi sangat krusial. Lebih dari itu harga bahan-bahan memasak mengalami kenaikan sehingga warga berpenghasilan rendah yang telah kehilangan pekerjaannya cukup kesulitan untuk memenuhi kebutuhannya dengan harga yang tinggi di tempat perbelanjaan seperti pasar dan toko-toko sembako serta ditemukan penutupan.

Berangkat dari permasalahan yang disebutkan sebelumnya, beberapa warga RT 55 Kelurahan Karangwaru berinisiatif untuk bergotong-royong membantu warga yang terdampak dengan mendirikan GelarGulung atau Gerakan Lumantar Guyub Lung Tinulung. Gerakan ini secara lebih rinci terdiri atas 5 bentuk aksi: (1) Aksi mapping warga mandiri partisipatif; (2) Aksi tanggap darurat pangan; (3) Aksi sosial kemandirian ekonomi; (4) Aksi jejaring pangupa jiwa; dan (5) Aksi berkebun lumbung pangan. Kelima aksi tersebut direalisasikan dengan 4 tindakan antara lain : (1) Pemberian bantuan donasi sembako; (2) Persiapan gedung dan sarana yang berfungsi untuk warung, toko sembako, sekretariat, dan gedung logistik; (3) Pembangunan kolam ikan; dan (4) Pengembangan kebun sayur. Untuk saat ini tindakan tersebut sudah terealisasi dalam wujud Pelataranku, Mini Mart 55, Crisis Center 55, Cafetaria 55 dan ATM berteman. Salah satu upaya yaitu masyarakat terdampak dapat datang ke crisis center untuk mengambil bahan masak sesuai kebutuhan, bahan masak tersebut berasal dari bahan masak swasembada warga setempat atau uang yang telah dikumpulkan untuk membantu warga terdampak. Upaya swasembada ini memanfaatkan potensi yang telah disediakan pada Kelurahan Karangwaru.

Program "Gelar-Gulung" memiliki tujuan pada penguatan keberlanjutan sosial dan ekonomi kepada mereka yang terdampak, khususnya warga RT 55 RW 02 Kelurahan Karangwaru yang mengalami turbulensi ekonomi ketika pandemi. Program ini difokuskan untuk dapat berkelanjutan meskipun juga 
Farida Rahmawati, Ana Chusniatul Hidayah, Aida Nur Faizah, Ahmad Falahuddin, M. Adryan Okuputra Inovasi Gerakan Gelar Gulung sebagai Solusi Pemenuhan Pangan Mandiri di Kota Yogyakarta

berorientasi jangka pendek maupun menengah. Berkelanjutan di sini artinya adalah tidak hanya berupa ketahanan pangan semacam pemberian bantuan sembako, namun warga juga dituntut mandiri secara ekonomi dan pangan dengan pemberian bantuan berupa modal baik modal skill maupun terjaminnya penjualan karena dibeli oleh salah satu toko yang merupakan bagian dari program.

Secara lebih rinci, bentuk aksi dari kegiatan Gelar-Gulung dapat dijelaskan sebagai berikut. Pertama ialah aksi mapping mandiri partisipatif yang dilakukan oleh masyarakat. Aksi ini ditujukan sebagai pemetaan donatur, warga terdampak, dan warga potensial untuk diplot ke program-program yang direncanakan. Kemudian bentuk yang kedua adalah aksi tanggap darurat pangan. Aksi ini dijawantahkan dengan dibuatnya Crisis Center ' 55 yang merupakan swalayan non berbayar bagi mereka yang terdampak pandemi baik secara kesehatan maupun penghasilan. Bantuan ini berupa sembako yang dapat mereka ambil sesuai kebutuhan. Aksi yang ketiga adalah perwujudan kemandirian ekonomi warga masyarakat. Bentuk aksi ini dapat dilihat melalui kehadiran Koperasi Gelar-Gulung ‘55, Minimart '55, Agromart '55, Pelataranku, dan Cafetaria sebagai fasilitas dalam membangun kemandirian lokal.

Selanjutnya untukaksi keempat ialah jejaring pangupo jiwa. Aksi ini berkesinambungan dengan aksi kemandirian ekonomi - aksi nomor 3 merupakan ploting bagi aksi nomor

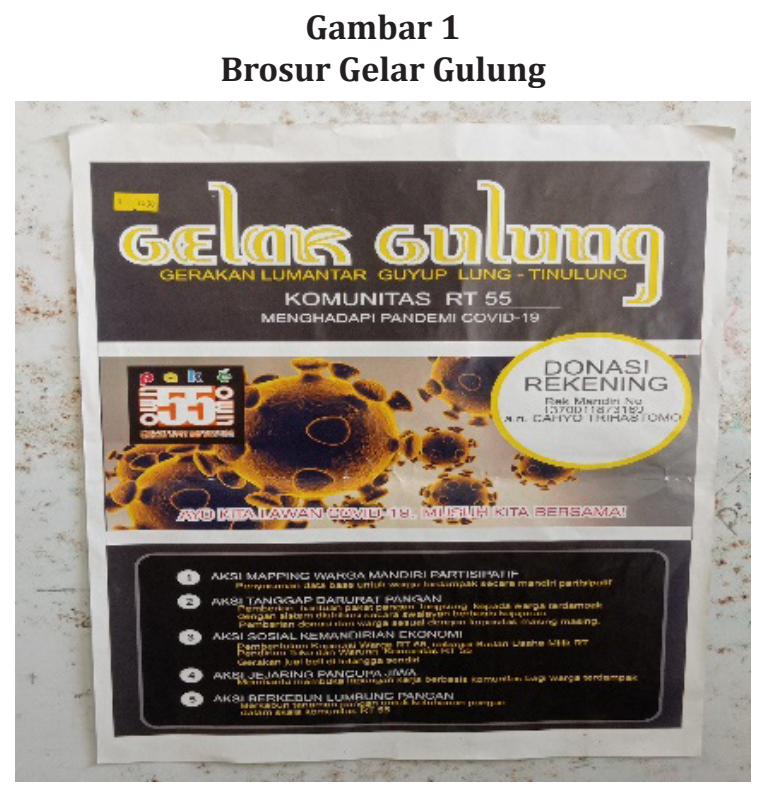

Sumber : Penulis, 2021
4. Mereka yang kehilangan pekerjaan maupun sumber pendapatan akibat pandemi dapat terbantu dengan adanya program-program yang telah direncanakan. Melalui inisiasi yang disebutkan sebelumnya muncul ruang akan penyerapan tenaga kerja sekaligus membuka ruang kapabilitas bisnis dalam bentuk penjualan makanan melalui program-program diatas. Terakhir adalah aksi berkebun lumbung pangan. Aksi ini merupakan perwujudan dari ketahanan pangan paling dasar. Warga masyarakat secara mandiri melakukan penanaman tanaman konsumsi dan budidaya ikan yang nantinya diolah dan dijual dalam program Agromart ' 55 secara siap saji.

\section{Diskusi}

Aksi Tanggap Masyarakat terhadap Pandemi COVID-19

Gelar-Gulung merupakan wujud aksi tanggap masyarakat terhadap efek pandemi COVID-19. Gerakan ini ditujukan untuk menciptakan keberlanjutan bagi warga masyarakat khususnya yang terdampak secara ekonomi, baik berupa kehilangan pekerjaan bagi karyawan maupun berkurangnya penjualan bagi para pedagang. Gerakan ini bertujuan tidak hanya memberi bantuan yang manfaatnya jangka pendek namun juga pengadaan berbagai program yang sifatnya simultan terhadap kemandirian ekonomi masyarakat dan ketahanan pangan dalam jangka panjang dan menengah. Permasalahan tersebut tidak akan teratasi apabila warga RT 55 tidak memiliki modal sosial yang kuat. Dengan kata lain, masyarakat tidak bisa bergerak secara individu namun harus bekerja sama dengan baik dalam mengatasi masalah. Melalui modal sosial yang kuat, gerakan sosial ini mampu terdorong dengan baik dan efisien. Salah satu bentuk modal sosial adalah terbentuknya kepercayaan di antara warga. Kepercayaan dalam gerakan ini terlihat dari adanya respon positif dari warga sehingga gerakan gelar gulung mampu menentukan 5 aksi prioritas.

\section{Aksi Mapping Mandiri Partisipatif}

Partisipasi warga RT 55 Kelurahan Karangwaru sangat penting dalam program kemasyarakatan karena partisipasi warga sangat berpengaruh terhadap keberhasilan program. Hal ini dapat dilihat dari penuturan wawancara dengan Pak Bandono. 
"ketika kami melakukan kerja bakti kami berembug (musyawarah) untuk membuat program yang mengacu pada warga yang terdampak COVID-19. Awalnya kami memplotting warga yang terdampak dan potensi warga terlebih dahulu, setelah itu memplotting donatur gerakan ini." (Pak Bandono, Wawancara 3 Juli 2021).

Langkah ini merupakan yang paling awal digagas oleh Bapak Bandono dan kawan - kawan dalam Program "Gelar-Gulung." Aksi ini di mulai dengan pemetaan warga terdampak, pemetaan donatur, dan pemetaan potensi warga. Pemetaan warga yang terdampak dilihat dari berbagai sisi, walaupun kemudian secara khusus melihat pada sisi dampak ekonomi yang ditimbulkan.

"Mapping warga terdampak dan potensi warga kami lakukan selama dua hari dan kami juga minta tolong sama ketua RT dan RW setempat, supaya aksi kami tepat sasaran." (Pak Bandono, Wawancara 3 Juli 2021).

Setelah menentukan warga yang terdampak, maka selanjutnya memetakan donatur yang dapat mendukung berjalannya program ini. Mapping donatur tidak hanya berkaitan dengan siapa saja yang bisa berdonasi, akan tetapi juga berkaitan dengan mapping komitmen warga dalam memberikan donasi. Donasi yang direncanakan yaitu donasi bantuan langsung sembako seperti uang tunai, kemudian donasi barang/alat, donasi lapangan kerja, pinjaman aset, dan pinjaman dana untuk pengembangan kegiatan yang berkelanjutan.

"kebetulan warga sini rata-rata memang warga menengah ke atas sehingga kami tidak kesulitan mapping donatur, toh mereka juga bukan orang kaya yang sombong (acuh tak acuh dengan warga lain). Mereka suka kalo dimintai tolong, ketika dengar program yang positif ya langsung transfer." (Pak Bandono, Wawancara 3 juli 2021)

"Selagi saya bisa bantu, ya saya usahakan membantu. Urip kui yo panggah tulung tinulung (saling membantu)." (Pak Agus, Wawancara 6 juli 2021)

Dalam hal ini partisipasi warga RT 55 terkait program Gelar Gulung bisa dikatakan berhasil. Hal ini nampak dalam bentuk hubungan sosial kuat yang sudah dibangun antar warga. Istilah tulung tinulung (saling membantu) sudah menjadi adat yang tidak bisa dinaifkan. Dalam aksi mapping mandiri partisipatif peran dari modal sosial sangatlah krusial. Modal sosial bukanlah modal dalam arti yang biasa saja seperti harta kekayaan atau uang, akan tetapi lebih ke arti kiasan bahwasannya modal sosial merupakan aset atau modal nyata yang penting dalam kehidupan bermasyarakat.

\section{Aksi Tanggap Darurat Pangan}

Dikatakan aksi darurat pangan karena aksi ini merupakan aksi yang berusaha untuk memenuhi kebutuhan energi manusia setiap harinya yaitu 2100 kkal. Banyak masyarakat yang terdampak tidak mampu untuk memenuhi energi tersebut karena kemampuan ekonomi yang menurun untuk membeli pangan. Kebutuhan akan pangan menjadi hal yang tidak bisa dianggap sepele. Bilamana kebutuhan pangan tidak mampu terpenuhi maka akan berdampak pada kesehatan dan kemampuan seseorang untuk bertahan hidup, terlebih menghadapi ancaman ketahanan kesehatan selama pandemi COVID-19.

Aksi ini berupa pemberian bantuan paket pangan langsung kepada warga terdampak dengan sistem distribusi melalui swalayan berbasis kejujuran. Swalayan ini menjual berbagai bahan pokok yang sebenarnya merupakan koperasi milik RT yang didirikan berdasar inisiasi Program Gelar-Gulung. Bilamana menilik swalayan ini, akan ditemukan ajakan "Ayo Belanja Sambil Bersedekah" yang di manatujuannya adalah mengajak mereka yang

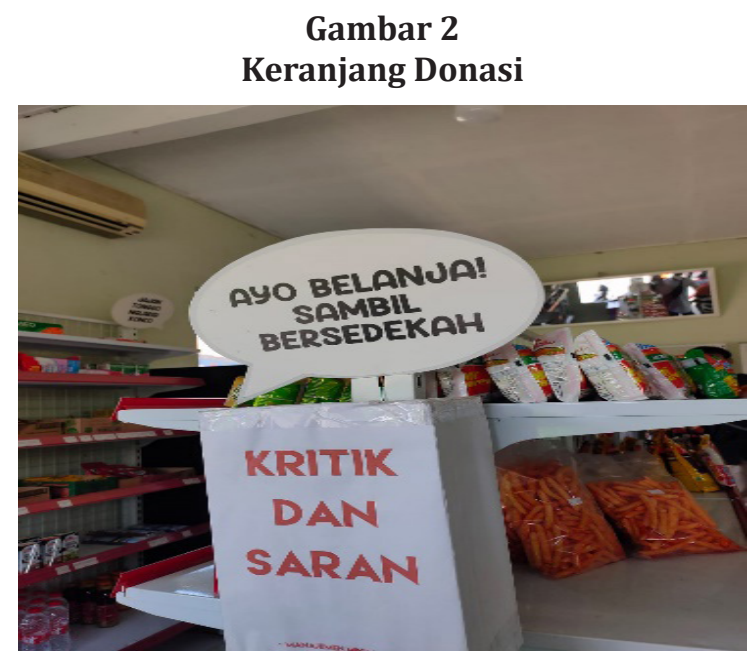

Sumber : Penulis, 2021 
Farida Rahmawati, Ana Chusniatul Hidayah, Aida Nur Faizah, Ahmad Falahuddin, M. Adryan Okuputra Inovasi Gerakan Gelar Gulung sebagai Solusi Pemenuhan Pangan Mandiri di Kota Yogyakarta

memiliki kelebihan materi untuk bersedekah membantu masyarakat terdampak. Sistem sedekah yang diterapkan bisa berupa uang atau membeli barang berlebih yang lebihnya diletakkan di dalam keranjang donasi.

Sementara itu bantuan yang disediakan di minimart berupa bahan pangan seperti beras, telor, gula, mie instan dan beberapa kebutuhan pangan lainnya. Tidak ada batasan terkait pengambilan bantuan khususnya bagi warga yang terdampak bebas mengambil sesuai dengan kebutuhan mereka. Bahkan bantuan tidak hanya dikhususkan untuk warga RT 55 saja, namun boleh dari warga sekitar dengan bermodal rasa saling percaya.

"kami gak tau warga dari luar RT kami itu benar-benar terdampak apa tidak, kami percaya aja kan kami niatnya nolong mungkin saja mereka memang membutuhkan. Kalo mereka niat ngambil untuk di timbun dan merugikan kami ya gak mungkin juga mereka setiap hari ngambilnya, pasti mereka ya sungkan sendiri (malu)." (Pak Bandono, Wawancara 3 Juli 2021).

Berdasarkan kutipan wawancara bersama Pak Bandono di atas, menunjukkan bahwa modal sosial rasa saling percaya menjadi pegangan utama dalam aksi tanggap darurat pangan. Kesimpulan wawancara ini relevan dengan teori yang diungkapkan Field yang membahas tentang modal sosial kepercayaan, yang menyatakan bahwa jaringan dengan kepercayaan tinggi bisa befungsi dengan baik dibandngkan dengan jaringan yang memiliki kepercayaan rendah.

\section{Aksi Sosial Kemandirian Ekonomi}

Kemandirian merupakan salah satu tujuan dari proses pemberdayaan. Barnadib mengatakan arti kemandirian itu ialah keadaan seseorang yang dapat menentukan diri sendiri dimana dapat dinyatakan dalam tindakan atau perilaku seseorang. Hal ini kemudian dinilai dari perilaku yang mampu berinisiatif, mampu mengatasi masalah dan hambatan, mempunyai rasa percaya diri, dan dapat melakukannya tanpa bantuan orang lain (Misjaya et al., 2019). Kaitannya dengan kemandirian ekonomi, di sini dapat diartikan sebagai memaksimalkan segala potensi di bidang ekonomi. Kemampuan dan potensi tersebut dilakukan secara mandiri atau tidak bergantung terhadap pihak lain, hal ini dapat berlaku individu maupun sosial antar masyarakat tanpa bergantung pada pemerintah.

Perwujudan dari kemandirian ekonomi ini dapat dilihat dalam Gelar Gulung. Dibangunnya Swalayan pusat krisis memberi harapan pada kemandirian yang tidak hanya secara jangka pendek melalui paket sembako, namun juga secara jangka panjang dengan memberi ruang berjualan. Warga RT 55 yang memiliki usaha secara ekslusif dapat menitipkan produknya ke swalayan ini, sehingga perputaran uang tidak sampai keluar wilayah sesuai dengan selogan dari warga oleh warga untuk warga. Selain itu, dibuatnya program-program seperti Koperasi Gelar-Gulung ‘55, Agromart yang menyediakan makanan olahan dari Aksi berkebun lumbung pangan, dan Pelataranku turut melatih kemandirian masyarakat di tengah pandemi.

\section{Gambar 3}

Minimart 55'

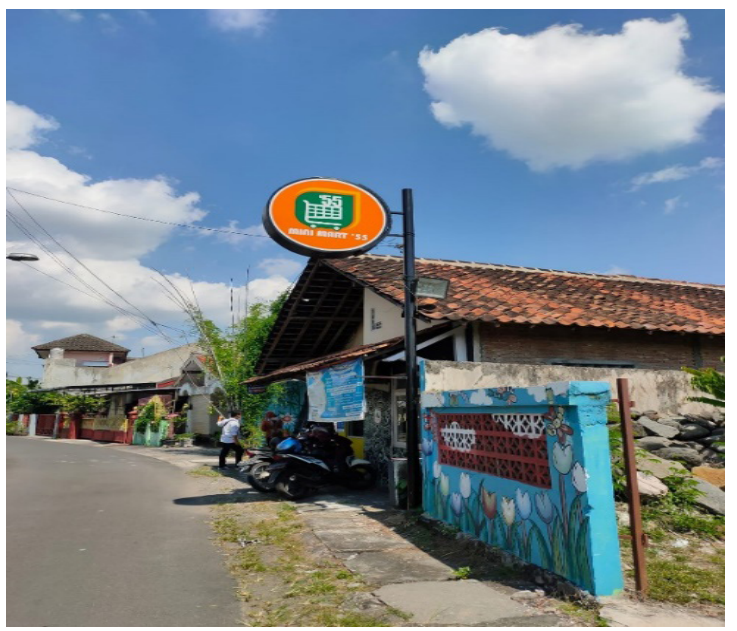

Sumber: Penulis, 2021

\section{Aksi Jejaring Pangupa Jiwa}

Aksi Jejaring Pangupa Jiwa ini merupakan perwujudan dari kemandirian ekonomi yang dijalankan untuk membiasakan warganya mandiri secara ekonomi. Dalam hal ini dengan dibukanya lapangan kerja berbasis komunitas bagi warga terdampak secara berkelanjutan. Komunitas di sini terbentuk berdasar mapping yang telah dilakukan pada aksi nomor 1 . Penggolongan warga terdampak berdasar potensinya kemudian mendapatkan pekerjaan di sini baik itu sebagai pekerja di tempat-tempat yang dibangun maupun sebagai penyuplai barang-barang yang dijual. Aksi ini dijalankan sebagai perwujudan warga yang mandiri secara ekonomi. Mereka yang penghasilannya 
terdampak pandemi tidak hanya dibantu berupa sembako terus menerus yang manfaatnya hanya jangka pendek saja, namun juga didorong untuk mandiri dan berpenghasilan sendiri. Hal ini dilakukan dengan cara mempekerjakan mereka yang menganggur akibat PHK oleh karena pandemi, dengan diserap untuk menjadi tenaga kerja di program yang direncanakan. Pedagang yang penjualannya terhambat selama pandemi, dagangannya turut diserap ke dalam programprogram. Tentu saja mereka tidak merasa mendapatkan bantuan secara cuma-cuma. Semua itu adalah hasil dari mereka sendiri dan dalam jangka panjang dapat dilanjutkan menjadi mata pencaharian utama meskipun pandemi sudah berakhir.

"Pemilihan aksi pangupa jiwa ini direncanakan supaya orang-orang sini yang terdampak Pandemi gak hanya nunggu bantuan dari pemerintah aja. Adanya koperasi dan rumah makan ini agar warga bisa memanfaatkan peluang untuk mandiri" (Bandono, Wawancara 03 Juli 2021).

\section{Aksi Berkebun Lumbung Pangan}

Aksi ini merupakan bentuk dari kemandirian ekonomi yang dibentuk sesuai dengan pemetaan potensi masyarakat pada aksi pertama. Dalam aksi berkebun lumbung pangan ini terdapat dua plot program yakni kolam ikan dan kebun sayur. Pembangunan kolam ikan sendiri memanfaatkan lahan kosong di Latar Srawung RT 55 RW 02. Pembuatan kolam ikan ini cukup terbantukan dengan kondisi lahan yang merupakan bekas kolam ikan dan sudah memiliki intalasi air. Kolam ikan dibuat dengan metode membran. Metode ini dianggap paling efektif karena hanya memerlukan lahan kosong, sehingga ketika lahan tersebut diperlukan untuk kegunaan lain pembongkaran yang dilakukan tidak terlalu besar jika dibandingkan dengan kolam metode keramik. Selain itu, metode membrane juga lebih protektif terhadap ikan-ikan di dalamnya daripada tanah biasa, karena metode tanah biasa berpotensi longsor maupun dibuat rumah tikus.

"Di sini kami mencoba memanfaatkan potensi warga yang ada se maksimal mungkin. Bahkan warga yang tidak ada keahlian dibidang pertanian maupun budidaya ikan, hanya dengan memiliki sebidang tanah kosong yang dapat dimanfaatkan untuk penanaman hidroponik maupun dibangun kolam ikan dengan metode membrane." (Pak Yoyok, wawancara 6 Juli 2021).

Kemudian dibangunjuga pengembangan kebun sayur sebagai upaya pemaksimalan potensi warga berikutnya dari pemberdayaan masyarakat guna membekali mereka untuk kemandirian ekonomi kedepannya. Program ini diperuntukkan bagi mereka yang memiliki lahan pribadi yang cukup untuk ditanami dan juga lahan kosong di belakang Swalayan Minimart '55. Media tanam selain tanah di sini juga memanfaatkan hidroponik dan polybag. Untuk pemupukan dilakukan kombinasi pupuk kandang dan organik. Program ini dicanangkan untuk manfaatjangka panjangyakni kemandirian ekonomi mereka yang mengikuti program dan ketahanan pangan bagi penduduk sekitar.

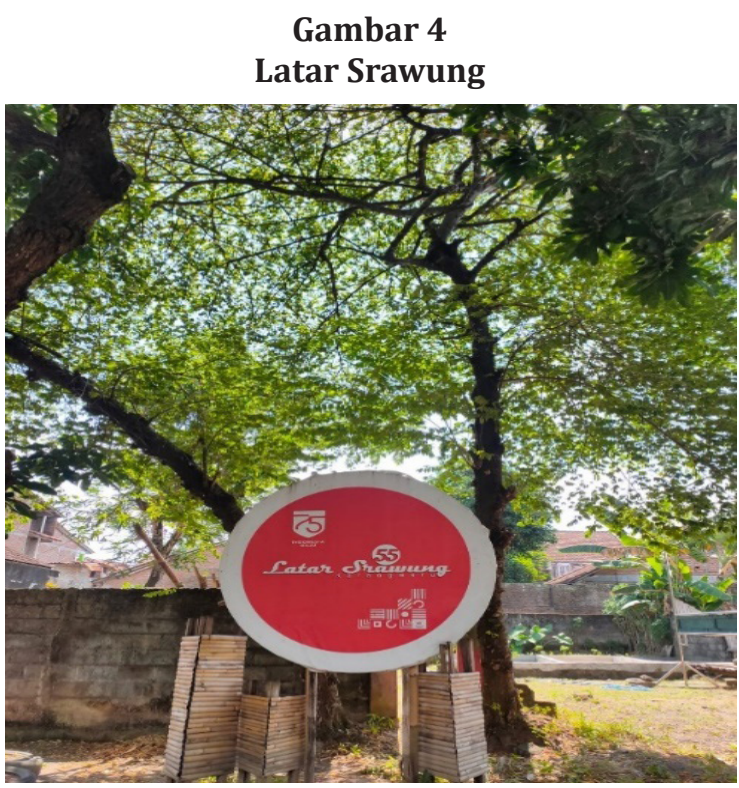

Sumber: Penulis, 2021

Kontribusi konklusif gerakan Gelar Gulung terhadap kemandirian ekonomi dan ketahanan pangan

Adanya program Gelar Gulung (Gerakan Lumantar Guyub Lung Tinulung) yang muncul karena jiwa sosial masyarakat yang kuat mendukung ketahanan pangan dan kemandirian ekonomi warganya. Pendapat beberapa warga pun terkait gerakan ini benar-benar bermanfaat, khususnya terkait konsep oleh warga, dari warga, dan untuk warga terealisasi. Kepedulian sosial serta unggulnya beberapa komponen masyarakat mampu membuat mereka bersatu menangani dampak COVID-19 yang belum tahu 
Farida Rahmawati, Ana Chusniatul Hidayah, Aida Nur Faizah, Ahmad Falahuddin, M. Adryan Okuputra Inovasi Gerakan Gelar Gulung sebagai Solusi Pemenuhan Pangan Mandiri di Kota Yogyakarta

kapan berakhirnya. Bukan hanya warga tak berdaya yang diberdayakan dengan program ini akan tetapi mencakup warga yang sudah berdaya akan tetapi belum maksimal atau kekurangan modal ekonomi.

"Alhamdulillah ya mas, saya bersyukur dan merasa terbantu. Kalo dagangan lagi sepi ya saya nyuwun mie sama telur di minimart buat makan malam" (Ibu Sri , wawancara 12 Juli 2021)

Seperti yang telah dipaparkan sebelumnya, adanya inovasi terkait masyarakat ataupun pemberdayaan masyarakat yang berhasil akan mendorong kesejahteraan warganya sendiri. Pemberdayaan memiliki dua arah tujuan yaitu berjuang untuk menghilangkan belenggu kemiskinan dan keterbelakangan, dan memperkuat status kelas masyarakat dalam struktur masyarakat (Kartasasmita, 1996). Banyaknya jumlah masyarakat yang berdaya akan membuat masyarakat tidak bergantung dengan bentuan dari pemerintah akan tetapi mampu mendorong pada kemandirian (Wahyuni, 2018). Bukti nyata dari pemberdayaan di RT 55 ini mencakup aksi mapping mandiri partisipatif. Aksi pemetaan ini ditujukan bagi warga yang memiliki potensi untuk terlibat dalam programprogram yang sudah direncanakan. Sementara pada aksi jejaring pangupo jiwa masyarakat yang kehilangan pekerjaan maupun sumber pendapatan akibat pandemi, dibantu untuk penjualannya dan bahkan dicarikan pekerjaan bagi mereka yang tidak memiliki pekerjaan.

Gerakan Gelar Gulung yang dilakukan mendapat respon positif dari warga baik warga RT 55 maupun warga diluar RT 55. Gerakan ini juga mendapat apresiasi dari Wakil Wali Kota Yogyakarta yaitu bapak Heroe Perwadi. Beliau berharap bisa dikembangkan juga di daerah lain karena konsep kegiatan yang dilaksanakan memiliki program yang berkelanjutan yang mendukung kemandirian ekonomi. Sedangkan Kepala Dinas Pemberdayaan Masyarakat Perempuan dan Perlindungan Anak Kota Yogyakarta Bapak Edy Muhammad menyatakan bahwa gerakan ini merupakan gerakan murni yang berasal dari warga dan bukan hanya sekedar keberpihakan terhadap warga terdampak tetapi sudah masuk dalam upaya pemulihan dampak sosial dan ekonomi (Arifa, 2020). Mas Bintang, salah satu pegawai Badan Perencanaan Pembangunan Daerah (BAPPEDA) juga memberikan apresiasi terhadap program Gelar Gulung ini.

"Gerakan Gelar Gulung ini bagus banget lo, sebenanya juga sudah banyak daerah yang melakukan aksi darurat tanggap covid, tapi belum ada yang punya konsep se inovatif Kelurahan Karangwaru." (Mas Bintang, Wawancara Juli 2021).

Selain itu menurut Ibu Yuli, salah satu warga yang mendapatkan bantuan mengatakan bahwa beberapa aksi di dalam gerakan Gelar Gulung tidak akan berjalan saat masa pandemi saja, akan tetapi bisa menjadi benteng pertahanan aksi tanggap darurat terhadap bencana yang akan datang, karena adanya gerakan gelar gulung ini membuat hubungan antar warga semakin kuat. Seperti halnya kesadaran masyarakat terhadap sesama semakin tinggi, warga yang hidup berkecukupan sadar bahwa dengan membeli di minimarket dapat menolong sesama warga lain dan warga kekurangan merasa dibantu dan diperhatikan oleh warga se RTnya. Rasa kebersamaan dan sikap kepedulian masyarakat membuat gerakan yang sudah terbentuk ini semakin kuat. Keterkaitan antar stakeholder dan pemerintahan memberikan multiplier effect bagi masyarakat dalam jangka pendek, menengah, maupun jangka panjang.

Crisis Center '55 yang merupakan aksi Tanggap darurat Pangan dengan memberikan sembako sesuai kebutuhan warga. Tidak hanya menyasar pada warga RT 55 saja akan tetapi melayani semua orang yang merasa terdampak dan kekurangan bahan pangan, baik dari RT sekitar maupun RW sekitar.

"Bahkan beberapa warga RT sebelah datang ke crisis center minta sembako, ya kami layani aja. Karena memang sebenarnya warga $R T$ kami sendiri yang terdampak tidak terlalu banyak. Jadi, ya kami malah menyasar warga dari luar kawasan kami." (Bapak Bandono, Wawancara 6 Juli 2021).

Dari pernyataan narasumber diatas, menjelaskan bahwa siapapun yang datang dan memerlukan bantuan, crisis center siap membantu tanpa pamrih. Salah satu warga bernama Ibu Risma (pedagang sempol) mengatakan bahwa dia tidak pernah merasa kekurangan semenjak gerakan Gelar Gulung dijalankan meskipun penjualan menurun 
drastis karena dampak pandemi. Ketika ia membutuhkan bahan pangan ia selalu di siapkan dengan baik oleh warga yang sedang bertugas di Crisis Center '55.

Poin penting dalam gerakan ini adalah mampu mendorong kemandirian ekonomi dengan dibangunnya Koperasi Gelar Gulung '55, Minimart '55, Agromart '55, Pelataranku, dan cafeteria. Masyarakat diberdayakan untuk pengelolaan cafeteria ataupun pengelolaan kolam sebagai imbalannya mereka diberikan upah perawatan. Hasil penjualan di minimarket selain untuk membeli kebutuhan sembako untuk crisis center sisanya masuk menjadi kas warga. Kondisi setelah adanya program ini mampu merubah keadaan sosial ekonomi akibat pandemi. Selain itu semenjak adanya gerakan ini kesadaran masyarakat untuk bergotong royong dan rasa solidaritasnya semakin tinggi. Bagi masyarakat mampu mereka bersedia memberikan donasi kebutuhan warga yang terdampak dengan senang hati, sehingga konsep lung tinulung warga terjalin dengan erat.

Dengan program yang dijalankan oleh gerakan Gelar-Gulung ini jelas memberi dampak bagi masyarakat kaitannya dalam kemandirian ekonomi. Hal ini sejalan dengan pendapat Kuswandoro (2016) yang menyatakan bahwa pemberdayaan dengan berdasarkan kemampuan dan kemandirian merupakan kunci dan prasyarat dari aktivitas desa membangun. Konsep pemberdayaan merangkup nilai-nilai sosial dan mengikuti paradigma pembangunan yang bersifat "people centered", partisipatif, dan berkelanjutan (Kuswandoro, 2016).

Seperti yang telah dijelaskan, program yang ada dalam gerakan ini mengusung semangat dari warga oleh warga dan untuk warga. Aksi-aksi khususnya sosial kemandirian ekonomi dan pangupo jiwa jelas secara langsung menstimulus warga untuk memaksimalkan potensinya guna memanfaatkan program-program seperti Minimart '55, Agromart '55, maupun Cafetaria. Karena tidak menutup kemungkinan dalam jangka panjang akan terjadi persaingan positif diantara warga dalam menyuplai dagangan maupun tenaga di tempat-tempat tersebut.

"Warga itu sangat antusias sama programprogram ini. kadang malah ibu-ibu itu berebut buat jaga di minimarket sama crisis center. Kami nyaman hidup bersosial seperti ini." (Ibu Fitri, Wawancara 9 Juli 2021).
"Orang-orang yang penghasilannya menengah ke atas itu lo, alhamdulillahnya ya paham sama lingkungan sekitar. Mereka merasa kalau mereka membeli di minimartitu akan membantu masyarakatyang terdampak COVID-19 ini" (Bapak Bandono, Wawancara 3 Juli 2021).

Kemudian ketahanan pangan di sini sesuai dengan definisi pada kajian literatur. Menurut Arifin dimensi ketahanan pangan adalah (a) ketersediaan: produksi, distribusi pangan pokok dan lainnya, berkualitas, aman, bergizi dan berimbang, (b) aksesibilitas: akses pangan, terutama kaum miskin/marginal: subsidi penanggulangan bencana, gender. (c) stabilitas harga: antar daerah, antar waktu, antar pelaku, konsep cadangan besi, cadangan penyangga, (d) utilisasi: pengolahan, keamanan, pola makan, higienis, sanitasi air, kehalalan, keutuhan, kemanfaatan dan sebagainya (Helmi \& Ali, 2020) to analyze the external and internal factors that affect food security and to formulate strategies for improving food security to facing COVID-19's pandemic in Bukittinggi. The primary data was collected by conducting a focus group discussion, indepht interview and questionnaire filling with purposive sampling technique. The results of descriptive analysis of secondary data indicate that the existing condition of food security in the Bukittinggi shows that the situation of food affordability is the best. The formulation of strategies for improving food security uses the analysis of Internal Factor Evaluation (IFE. Bentuk ketahanan pangan sebagai efek dari adanya Gerakan ini di RT 55 ini bisa dikatakan memenuhi persyaratan tersebut. Dalam hal ketersediaan, dicukupi oleh Minimarket untuk saat ini dan Lumbung Pangan dalam jangka panjang. Kemudian aksesibilitas, ditunjukkan dengan berdirinya Minimart '55 yang mudah dijangkau dan gratis bagi warga terdampak. Lalu stabilitas harga yang telah dibuktikan dengan kemampuan Minimart '55 menjual produk dengan harga yang terjangkau dibandingkan toko lainnya. Selain itu teridentifikasi utilitas yang mana dalam program Agromart '55 dalam pengolahannya murni dari orang dalam. Hambatan terhadap program ini muncul karena warga pernah lengah terhadap kegiatan warga sehingga kasus covid tiba-tiba meningkat. Warga yang berkaitan langsung dengan pengelolaan minimarket terkena covid dan harus melakukan 
Farida Rahmawati, Ana Chusniatul Hidayah, Aida Nur Faizah, Ahmad Falahuddin, M. Adryan Okuputra Inovasi Gerakan Gelar Gulung sebagai Solusi Pemenuhan Pangan Mandiri di Kota Yogyakarta

isolasi mandiri sehingga berdampak pada operasional program.

Berdasarkan hasil wawancara bersama pengurus, ke depannya program gelar gulung ini akan melakukan permohonan badan hukum. Dengan adanya badan hukum kegiatankegiatan yang akan dilakukan nanti terdaftar dan terlindungi oleh hukum negara. Selain itu pengembangan akan ada program-program lainnya yang dapat membantu masyarakat sekitar dan menghidupkan perekonomian seperti program koperasi simpan pinjam, dan lain sebagainya. Harapan kedepannya program ini dapat menjangkau lebih luas tidak hanya bermanfaat untuk RT 55 RW 2, akan tetapi juga bisa bermanfaat untuk warga Yogyakarta.

\section{Kesimpulan}

Gerakan Gelar Gulung atau Gerakan Lumantar Guyub Lung Tinulung merupakan inisiatif dari komunitas masyarakat RT 55 Kelurahan Karangwaru sebagai solusi untuk mewujudkan ketahanan pangan dan kemandirian ekonomi dengan pemberdayaan masyarakat pada masa pandemi. Gerakan tersebut terdiri dari 5 aksi yakni : (1) Aksi mapping warga mandiri partisipatif; (2) Aksi tanggap darurat pangan; (3) Aksi sosial kemandirian ekonomi; (4) Aksi jejaring pangupa jiwa; dan (5) Aksi berkebun lumbung pangan. Kelima aksi tersebut direalisasikan dengan 4 tindakan antara lain : (1) Pemberian bantuan donasi sembako; (2) Persiapan gedung dan sarana yang berfungsi untuk warung, toko sembako, sekretariat, dan gedung logistik; (3) Pembangunan kolam ikan; dan (4) Pengembangan kebun sayur. Untuk saat ini tindakan tersebut sudah terealisasi dalam wujud Pelataranku, Mini Mart 55, Crisis Center 55, Cafetaria 55 dan ATM berteman.

Melalui modal pembiayaan pribadi warga, rasa solidaritas yang erat, kepercayaan yang tinggi, tenggang rasa dan pemanfaatan lahan program ini dapat berjalan lancar hingga saat ini. Gerakan ini kemudian dapat membantu warga yang sangat terdampak dan warga yang terkena virus COVID-19 dalam mempertahankan hidup serta kemaslahatan bersama. Hasil dari swasembada berupa tanaman sayur dan budidaya perikanan dijual kembali kepada warga dengan harga yang murah. Hal ini dilakukan untuk mengatasi inflasi harga bahan makanan yang mengalami peningkatan. Selain itu juga menjaga ketersediaan bahan makan pokoksecara gratis untuk warga yang sedang isolasi mandiri karena terjangkit virus COVID-19. Gelar Gulung telah mampu membantu pemulihan kondisi warga RT 55 dengan membantu mencarikan lapangan pekerjaan serta memberi solusi pemenuhan kebutuhan pangan masyarakat desa. Selain itu gerakan ini juga membantu dalam meningkatkan rasa kepedulian terhadap sesama. Di sisi lain keberadaan Gelar Gulung menjadi sarana rekreasi warga menghabiskan waktu luang untuk menghilangkan rasa bosan saat pemberlakuan pembatasan. Upaya swasembada ini memanfaatkan potensi yang telah disediakan pada Kelurahan Karangwaru.

\section{Referensi}

Arifa, R. E. (2020, 8 May). Gerakan Gelar Gulung Ajak Saling Bantu Atasi Dampak Ekonomi COVID-

19 di Yogya. https://jogja.antaranews.com/ berita/424647/gerakan-gelar-gulung-ajaksaling-

bantu-atasi-dampak-ekonomi-covid-19-diyogya. accessed on 13 Juli 2021

Awalurrizqi, M., Sumantiyasmi, A. R., \& Azzahidah, A. (2021). Kolaborasi Komunitas Stucash dan Lakoni dalam Penanganan Dampak SosialEkonomi Pandemi COVID-19. Journal of Social Development Studies, 2(1), pp. 14-27.

Ansari, S., Munir, K., \& Gregg, T. (2012). Impact at the 'Bottom of the Pyramid': The Role of Social Capital in Capability Development and Community Empowerment. Journal of Management Studies, 49(4), pp. 813-842.

Bahtiar, R. A., \& Saragih, J. P. (2020). Dampak Covid-19 terhadap perlambatan ekonomi sektor umkm. Jurnal Bidang Ekonomi Dan Kebijakan Publik, 7(6), pp. 19-24.

Fathy, R. (2019). Modal sosial: Konsep, inklusivitas, dan Pemberdayaan masyarakat. Jurnal Pemikiran Sosiologi, 6(1), pp. 1-17.

Helmi, F., \& Ali, H. (2020). Strategi Peningkatan Ketahanan Pangan Dalam Menghadapi Pandemi Covid-19 Di Kota Bukittinggi.Jurnal Benefita, 5(3), pp. 366-382. doi: https://doi. org/10.22216/jbe.v5i3.5480

Kuswandoro, W.E. (2016). Strategi pemberdayaan masyarakat desa berbasis partisipasi. In: Wardiyanto, B., Aminah, S., \& Martanto, U. (Eds). Percikan Pemikiran Tata Kelola Dan Pembangunan Desa (pp. 380-391). Surabaya: Airlangga University Press. 
Misjaya, M., Bukhori, D. S., Husaini, A., \& Syafri, U. A. (2019). Konsep Pendidikan Kemandirian Ekonomi Di Pondok Pesantren Mukmin Mandiri Sidoarjo - Jawa Timur. Edukasi Islami: Jurnal Pendidikan Islam, 8(01), pp. 91-108. doi: https://doi.org/10.30868/ ei.v8i01.371

Nasution, A. (2016). Peranan Modal Sosial Dalam Pengurangan Kemiskinan Rumah Tangga Di Perdesaan Indonesia. Jurnal Ekonomi dan Kebijakan Publik, 7(2), pp. 171-183.

Pangaribowo, E. H., Gerber, N., \& Torero, M. (2013). Food and nutrition security indicators: a review. (ZEF Working Paper No. 108). Bonn. doi: http://dx.doi.org/10.2139/ ssrn.2237992

Pangestu, A. G., Saputro, I. A., Umami, R., \& Sholikah, I. (2020). Sendangagung Bangkit: Bangun Kemandirian Pangan dan Ekonomi Desa Di Masa Pandemi Covid-19 (Sendangagung Bangkit: Building Food Security and Rural Economy in The Covid-19 Pandemic). 2(Khusus 2), pp. 197-205.
Salim \& Syahrum. (2012). Metodologi Penelitian Kualitatif. Bandung: Citapustaka Media.

Satuan Tugas Penanganan COVID-19 Indonesia. (2021). Peta Sebaran. https://covid19.go.id/ peta-sebaran

Syahli, R., \& Sekarningrum, B. (2017). Pengelolaan sampah berbasis modal sosial masyarakat. Sosioglobal: Jurnal Pemikiran dan Penelitian Sosiologi, 1(2), pp. 143-151.

Tampubolon, J., Sugihen, B. G., Samet, M., Susanto, D., \& Sumardjo, S. (2006). PEMBERDAYAAN MASYARAKAT MELALUI PENDEKATAN KELOMPOK (Kasus Pemberdayaan Masyarakat Miskin melalui Pendekatan Kelompok Usaha Bersama (KUBE). Jurnal Penyuluhan, 2(2). pp. 10-22. doi: https:// doi.org/10.25015/penyuluhan.v2i2.2122

Wahyuni, D. (2018). Strategi Pemberdayaan Masyarakat Dalam Pengembangan Desa Wisata Nglanggeran, Kabupaten Gunung Kidul. Aspirasi, 9(1), pp. 83-100. 